\title{
Makam Kuno Belanda (Kerkhof) di Kabupaten Ngawi dan Potensinya Sebagai Sumber Belajar Sejarah Lokal
}

\author{
Novi Triana Habsari*
}

\begin{abstract}
Abstrak
Makam Kuno Belanda (Kerkhof) merupakan salah satu jejak peninggalan Kolonialisme Belanda di Kabupaten Ngawi. Latar belakangsejarah Makam Kuno Belanda (Kerkhof), memiliki nilai-nilai sejarah yang bisa diwariskan ke generasi sekarang sebagai sumber belajar sejarah. Lokasinya terletak Kelurahan Pelem Kecamatan Ngawi Kabupaten Ngawi. Makam Kuno Belanda dibangun pada tahun 1885 dibawah pimpinan Gubernur Jendral Van Den Bosch pada waktu menjajah daerah Ngawi. Makam Kuno Belanda dibangun dengan tujuan untuk menguburkan tentara Belanda beserta keluarganya yang telah mati. Sebagai sumber belajar sejarah Ngawi dengan wilayahnya yang strategis merupakan daerah yang penting bagi Belanda untuk mendirikan benteng sehingga mempermudah untuk menguasai daerah sekitar.
\end{abstract}

Kata Kunci : Kerhcof, makam kuno, sejarah lokal

\section{Pendahuluan}

Kedatangan Belanda di Indonesia pertama kali dipimpin oleh Cournelis de Houtman tahun 1596 dan tiba di Banten. Rombongan kedua dipimpin oleh Jacob Van Neck tahun 1598 (Marmayadi, 2011). Pada masa kekuasaan kolonial Belanda di Indonesia tersebut, semua berbagai bidang kehidupan dijajah dan dimonopoli dari bidang politik, bidang perdagangan, bidang pendidikan, bidang sosial dan kebudayaan selama \pm 350 tahun.

Oleh sebab itu di Indonesia terdapat bangunan-bangunan bersejarah hasil peninggalan kolonial Belanda yang sampai saat ini masih bisa kita jumpai. Peninggalanpeninggalan isik masa penjajahan Belanda di Indonesia khususnya di Jawa dan Madura menurutPoesponegoro (2008: 27) antara lain, jalan kereta api dan bangunan- bangunan irigasi di Brantas dan Demak, selain itu terdapat peninggalan-peninggalan dari Belanda berupa pabrik gula, dan benteng-benteng seperti yang dibangun dan digunakan saat penguasaan daerah Madiun dan sekitarnya. Salah satunya Belanda membangun benteng pertahanan di daerah Ngawi yang dikenal dengan sebutan Benteng Van Den Bosch.

Benteng Van Den Bosch adalah salah satu bangunan peninggalan masa penjajahan Belanda oleh masyarakat disebut dengan Benteng Pendem yang berada di Desa Pelem, Kecamatan Ngawi, Kabupaten Ngawi merupakan salah satu jejak sejarah kolonial Belanda di Indonesia.

Adanya benteng tersebut, tidak terlepas dari tentara Belanda beserta anggota keluarganya yang tinggal di sekitar benteng. Mereka tinggal tidak hanya satu 
atau dua tahun saja, tetapi secara turun temurun. Hal ini dibuktikan dengan adanya makam orang-orang Belanda yang berada tidak jauh dari benteng Pendem. Makam tersebut berbeda dengan makam pada umumnya di Indonesia.

Pembeda antara makam Belanda tersebut dengan makam lokal adalah dari segi bangunannya serta tidak ada perawatan khusus seperti kebersihan lingkunganya. Bahkan makam lokal jauh lebih terawat. Hal ini dikarenakan sudah tidak adanya penduduk sekitar yang memperhatikan makam tersebut.

Makam Belanda ini bisa dijadikan salah satu sumber belajar sejarah. Ngawi merupakan daerah strategis dan menguntungkan bagi Belanda. Daerah Ngawi digunakan Belanda untuk mendirikan benteng pertahanan agar memudahkan Belanda menguasai dan menyerang wilayah sekitar Ngawi, yaitu daerah Solo dan Madiun.

Berkata tentang mata pelajaran sejarah, sebenarnya dapat lebih disukai bahkan dicintai oleh siswa. Hal tersebut sesuai yang diungkapkan oleh Ir. Soekarno pada saat berpidato dalam rangka memperingati Hari Pahlawan tanggal 10 November 1961, "Bangsa yang besar adalah bangsa yang menghormati jasa pahlawannya" (Arsip Nasional RI). Katakata tersebut mengisyaratkan bahwa seorang pahlawan, benda purbakala, dan bangunan-bangunan bersejarah itu sangatlah penting bagi generasi muda dan masyarakat. Seperti fungsi dari sejarah sebagai ilmu pengetahuan yang bisa bermanfaat bagi semua orang (Hamid dan Madjid, 2011: 87-89).

Sementara itu, saat ini masyarakat khususnya sekitar Makam Kuno Belanda kurang memahami asal muasal makam dan juga keterkaitannya dengan benteng van den bosh terlebih siswa SMP. Padahal keberadaannya di Desa Pelem tersebut juga dapat diaplikasikan ke dalam materi pembelajaran sejarah dengan mengacu kepada kurikulum KTSP dan kurikulum 2013 yaitu dengan cara mengkaitkannya ke dalam Kompetensi Dasar mengenai peninggalan-peninggalan pada masa penjajahan Belanda di Indonesia (Suastawan, 2014: 4).

Oleh karena itu, adanya bangunan tersebut menarik untuk dikaji terutama tentang latar belakang sejarah adanya makam kuno Belanda (Kerkhof), dan potensinya sebagai sumber belajar sejarah. Tujuan penelitian ini adalah 1). mengetahui latar belakang sejarah makam kuno Belanda (Kerkhof), 2). mengetahui makam kuno (Kerkhof) yang dapat dijadikan sebagai sumber belajar sejarah.

\section{Tinjauan Pustaka}

\section{A. Pengertian Makam}

Makam dalam Kamus Besar Bahasa Indonesia (1990: 503) mengandung dua makna, yaitu: (1) mengantarkan jenazah ke 
perkuburan, (2) kata benda yang artinya tempat tinggal atau kediaman. Menurut Soekmono (dalam Mulyani, 2013) dijelaskan bahwa makam merupakan wujud dari tiga kebudayaan yaitu gagasan, aktifitas, dan artefak. Makam berupa hasil aktifitas perbuatan manusia yang dapat diraba, dilihat dan bahkan didokumentasikan. Makam biasanya diabadikan dengan bangunan yang terbuat dari batu yang disebut jirat atau kijing. Bagi orang-orang penting, di atas jirat biasanya didirikan rumah yang disebut cungkup atau kubah.

Dari beberapa pengertian di atas dapat disimpulkan bahwa makam adalah tempat yang digunakan untuk mengubur jenazah sebagi tempat peristirahatan terakhir. Secara umum makam manusia memiliki arsitektur yang sama yaitu gundukan batu atau tanah yang diberi jirat atau kijeng sebagai penanda. Akan tetapi secara khusus, biasanya dingun rumah yang sering disebut cungkup atau kubah.

\section{B. Makam Kuno Belanda (Kerkhof)}

Secara umum masyarakat sudah mengetahui lokasi Benteng Van Den Bosch (Benteng Pendem) yaitu di Kabupaten Ngawi namun belum mengetahui apa sebenarnya tentang bangunan tersebut. Selain itu juga ada sebuah komplek makam warga Belanda yang dibangun pada abad 18. Makam tersebut digunakan untuk memakamkan jenazah para penjajah Belanda yang meninggal pada waktu menguasai daerah Ngawi. Pemakaman warga Belanda (kerkhof) ini letaknya sudah diluar komplek Benteng Van Den Bosch. Lokasinya sekitar \pm 200 meter ke arah barat daya, dari Jl. Pangeran Diponegoro masuk Jl. Monginsidi, atau tepatnya di Kelurahan Pelem Kecamatan Ngawi Kabupaten Ngawi. Kerkhof ini kemungkinan di dirikan pertama kali pada tahun 1885 yang ditandai pada pintu gerbang masuk.

Makam ini diperuntukkan sebagai tempat peristirahatan terakhir bagi warga Belanda yang wafat di wilayah Ngawi, akan tetapi sekarang sudah berbaur dengan kompleks pemakaman umum. Beberapa nisan sudah di beri tanda nomor yang bertujuan untuk pendataan dan pelestaraian, mengingkat karena nisan di Kerkhof ini berusia cukup tua sehingga turut menjadi benda cagar budaya (kurniawan, 2013: 5).

Berdasarkan penjelasan diatas maka dapat disimpulkan tentang pengertian makam warga Belanda (kerkhof) adalah tempat pemakaman warga Belanda mulai tahun 1885 yang tinggal di daerah Ngawi pada waktu penguasaan daerah Ngawi dan sekitarnya. Tempat tersebut berfungsi sebagai tempat wisata edukasi dan tempat rekreasi berada di Kabupaten Ngawi yang bisa dinikmati oleh seluruh masyarakat.

\section{Sumber Belajar}

Belajar mengajar adalah suatu proses yang mengolah sejumlah nilai untuk dikonsumsi oleh setiap peserta didik. Nilainilai tersebut tidak datang dengan 
sendirinya, melainkan dari berbagai sumber. Sumber belajar yang sesungguhnya banyak sekali dan terdapat dimana-mana antara lain di sekolah, di halaman, di pusat kota, di pedesaan, dan sebagainya (Djamarah dan Zain, 2010: 122).

Begitu pula Association for Educational Communications an Technology (AECT) (dalam Komalasari, 2011: 108) mengatakan bahwa sumber pembelajaran adalah segala sesuatu atau daya yang dapat dimanfaatkan oleh guru, baik secara terpisah maupun dalam bentuk gabungan, untuk kepentingan belajar mengajar dengan tujuan meningkatkan efektifitas dan efesien pembelajaran.

Dengan demikian, sumber belajar merupakan segala sesuatu baik yang didesain maupun menurut sifatnya dapat dipakai atau dimanfaatkan dalam kegiatan pembelajaran untuk memudahkan belajar siswa. Dalam kaitannya sumber belajar sejarah berarti semua alat bantu yang digunakan dalam menerangkan mata pelajaran sejarah, sehingga siswa mampu menerima pengetahuan dengan mudah.

Sumber belajar bisa diperoleh sekolah, di lingkungan tempat tinggal, di pusat kota, di pedesaan, dan lain sebagainya. Sumber belajar juga dikelompokkan menjadi lima kategori, yakni manusia, buku/perpustakaan, media masa, alam lingkungan, dan media pendidikan. Namun untuk menjadikan sumber belajar yang tepat maka harus memilih dan memahami tentang pendekatan pembelajaran, strategi pembelajaran, metode pembelajaran, model pembelajaran, dan media pembelajaran. Karena tidak semua pendekatan, metode, model, dan media pembelajaran cocok digunakan dalam mata pelajaran sejarah.

1. Pendekatan Pembelajaran

Dalam kegiatan belajar mengajar yang berlangsung telah terjadi interaksi sosial antara guru dan peserta didik. Setiap guru diharapkan mampu melakukan proses tersebut dengan baik agar peserta didik dapat menerima materi pembelajaran dengan baik. Guru haruslah pandai memilih pendekatan secara arif dan bijaksana, bukan dengan sembarangan karena hal tersebut akan merugikan peserta didik. Serta pandangan seorang guru terhadap anak didik akan menentukan sikap dan perbuatan mereka (Djamarah dan Zain, 2010: 53-54).

Dalam pembelajaran sejarah, pendekatan konstruktivisme memungkinkan peserta didik melakukan dialog kritis dengan subjek pembelajar, menggali informasi sebanyak mungkin dari berbagai sumber untuk melakukan klasifikasi dan prediksi serta menganalisis masalah-masalah sejarah termasuk masalah sosial yang kontroversial yang dihadapinya (Supriatna dalam Aman, 2011: 109). 
Dari beberapa penjelasan di atas dapat disimpulkan bahwa pendekatan pembelajaran sangatlah penting untuk dilakukan oleh seorang guru dalam melakuakan kegiatan belajar mengajar. Karena dengan mampu memahami karakteristik siswa akan dengan mudah seorang guru dan peserta didik berinteraksi. Serta siswa akan mudah menerima materi pembelajaran, untuk mata pelajaran sejarah cocok menggunakan pendekatan konstruktivisme.

2. Strategi Pembelajaran

Secara umum strategi mempunyai pengertian suatu garis-garis besar haluan untuk bertindak dalam usaha mencapai sasaran yang telah ditentukan. Bila dihubungkan dengan belajar mengajar, strategi bisa diartikan sebagai pola-pola umum kegiatan guru anak didik dalam perwujudan kegiatan belajar mengajar untuk mencapai tujuan yang telah digariskan (Djamarah dan Zain, 2010: 5).

Dengan demikian strategi pembelajaran adalah kumpulan dari metode-metode dan pola-pola umum kegiatan antara guru dan anak didik dalam perwujudan kegiatan belajar mengajar untuk mencapai tujuan yang telah digariskan.

3. Metode Pembelajaran

Metode pembelajaran merupakan bagian integral dari strategi pembelajaran yang merupakan langkah- langkah taktis yang perlu diambil oleh pengajar sejarah dalam menunjang strategi yang hendak dikembangkan. Dengan sendirinya perlu pula disadari bahwa seperti halnya dalam hubungan strategi mengajar, sasaran akhir dari pelaksanaan metode mengajar tidak lain dari apa yang tercantum dalam perencanaan suatu pembelajaran (Aman, 2011: 110).

Metode-metode pembelajaran yang sering digunakan dalam mata pelajaran sejarah antara lain, metode reseptif, metode tanya jawab, metode diskusi, metode kerja kelompok, metode sosio drama, metode inkuiri, metode karyawisata, metode pembelajaran luar kelas, metode problem solving, dan lain sebagainya.

4. Model Pembelajaran

Menurut Aunurrahman (2009: 141) model pembelajaran adalah pola yang digunakan sebagai pedoman dalam merencanakan pembelajaran di kelas maupun di luar kelas.

Dengan demikian model pembelajaran adalah pola yang digunakan sebagai pedoman dalam merencanakan pembelajaran di kelas maupun di luar kelas. Setiap model pembelajaran memiliki ciri khusus serta kelebihan dan kelemahan masing-masing dibandingkan dengan model pembelajaran yang lainnya. 
5. Media Pembelajaran

Djamarah dan Zain (2010: 120) mengungkapkan bahwa media adalah sumber belajar, maka secara luas media dapat diartikan dengan manusia, benda, ataupun peristiwa yang memungkinkan anak didik memperoleh pengetahuan dan ketrampilan.

Dengan demikian media pembelajaran adalah alat bantu yang digunakan untuk mempermudah dalam menyampaikan materi pembelajaran oleh guru kepada siswanya.

Makam adalah salah satu sumber belajar sejarah. Di sekitar benteng Van Den Bosh, makam tersebut membuktikan bahwa orang Belanda pernah tinggal di daerah tersebut. Hal ini sesuai dengan mata pelajaran IPS SMP Kelas II semester I tentang kedatangan kolonialisme di Indonesia khsusnya bangsa Belanda.

\section{B. Sejarah Lokal}

\section{Pengertian Sejarah Lokal}

Menurut Ham (dalam Widja, 1991: 7) sejarah lokal hanya diartikan sebagai sejarah daerah tertentu, maka sejarah itu lama berkembang di Indonesia bahkan sejarah yang kita miliki sekarang bermula dari tradisi sejarah lokal seperti itu. Hal ini kita hubungkan dengan berbagai sejarah daerah dengan nama tradisional seperti babad, tambo, riwayat, hikayat, dan sebagainya, yang dengan cara-cara khas menguraikan asal-usul suatu daerah tertentu.

\section{Ruang Lingkup Sejarah Lokal}

Sejarah lokal edukatif-inspiratif adalah jenis sejarah lokal yang disusun dalam rangka mengembangkan kecintaan sejarah terutama pada sejarah lingkungannya (Widja, 1991: 46). Pendapat lain dijelaskan oleh Tilbury (1995: 199) bahwa pendidikan lingkungan tidak hanya terkait dengan masalah fisik-biologis, tetapi juga berhubungan dengan aspek estetika, ekonomi, sosial, politik, historis, dan budaya. Oleh karenanya banyak disiplin yang memiliki irisan terhadap pendidikan lingkungan hidup (Ahmad, 2013: 75).

Dengan demikian dapat disimpulkan bahwa ruang lingkup sejarah lokal berangkat dari lingkungan sendiri. Artinya, setiap daerah pasti memiliki cerita dan asalusul sejarahnya dan dari situlah disiplin ilmu sejarah lokal.

\section{Arti Peting Sejarah Lokal}

Menurut Finberg ahli, sejarah Inggris (dalam Widja, 1991: 15), untuk memahami arti pentig sebuah sejarah lokal perlu mengambil perumpamaan bahwa lingkungan keluarga, lingkungan komunitas, lingkungan nasional, dan lingkungan supranasional tak ubahnya sebagai serangkaian lingkaran sentris. Masingmasing perlu dikaji dengan mangacu pada lingkaran yang ada diluarnya, tanpa harus diartikan bahwa yang berada dilingkaran paling dalam adalah kurang sempurna, hanya karena dia ditutupi oleh lingkaranlingkaran diluarnya. Makam Belanda 
(kerkhof) masuk dalam kategori sejarah lokal karena merupakan peninggalan sejarah warga Belanda pada waktu berkuasanya tentara Belanda yang tinggal di daerah Ngawi.

Berdasarkan penjelasan diatas, dapat disimpulkan bahwa sejarah tidak semata-mata muncul begitu saja, tetapi sejarah yang besar terdiri dari sejarah yang kecil yang menjadi satu. Maka kajian sejarah lokal dipandang sebagai disiplin ilmu yang memiliki arti penting karena sejarah lokal bagian dari sejarah nasional.

\section{Metode Penelitian}

Penelitian ini dilaksanakan di kompleks pemakaman warga Belanda (kerkhof) Kelurahan Pelem Kecamatan Ngawi Kabupaten Ngawi. Penelitian ini menggunakan pendekatan kualitatif. Pendekatan kualitatif merupakan metode penelitian yang digunakan untuk meneliti pada kondisi obyek yang alamiah, disini peneliti adalah sebagai instrumen utama, teknik pengumpulan data dilakukan secara trianggulasi, analisis data bersifat induktif, dan hasil penelitian kualitatif menekan pada makna (Sugiyono, 2008: 205).

Pada dasarnya, penelitian kualitatif digunakan dalam penelitian yang merujuk pada objek dan fenomena yang terjadi secara alami. Adapun data yang akan diperoleh akan bersifat deskriptif karena menggunakan pendekatan induktif. Peneliti melakukan pengamatan atas permasalahan khusus yang ada di makam kuno Belanda (Kerkhof). Kemudian menarik kesimpulan secara umum dengan dukungan dari beberapa informasi, sehingga data yang akan diperoleh akan bersifat deskriptif.

Jenis penelitian yaitu deskriptif. Bagian deskriptif dalam catatan data ini meliputi potret subjek, rekonstruksi dialog, deskripsi keadaan fisik, struktur tentang tempat, dan barang-barang lain yang ada di sekitarnya. Demikian juga, catatan tentang berbagai peristiwa khusus (termasuk siapa yang terlibat dengan cara bagaimana, gerakgeriknya, dan juga tingkah laku atau sikap penelitiannya) (Sutopo, 2002: 74).

Pendekatan ini cocok untuk meneliti tentang latar belakang sejarah makam kuno Belanda sebagai sumber belajar sejarah lokal kepada masyarakat. Penelitian ini dilaksanakan dengan menganalisis data yang diperoleh dari wawancara, dokumentasi, dan observasi langsung di lapangan. Menurut Lofland (dalam Moleong, 2012: 157), sumber data utama dalam penelitian kualitatif ialah kata, dan tindakan, selebihnya adalah data tambahan seperti dokumen dan lain-lainnya. Sumber data penelitian ini merupakan sumber data primer dan sumber data sekunder yang dapat menjelaskan informasi yang diperlukan dalam penelitian.

Teknik pengumpulan data merupakan langkah yang paling strategis dalam penelitian, karena tujuan utama dari penelitian adalah mendapatkan data. Tanpa 
mengetahui teknik pengumpulan data, maka peneliti tidak akan mendapatkan data yang memenuhi standar data yang ditetapkan. Pengumpulan data dalam penelitian ini dilakukan dengan wawancara, observasi, dan dokumentasi tertulis/arsip (Sugiyono, 2008: 224).

Teknik analisis isi dokumen digunakan untuk memperoleh data atau informasi yang bersumber dari dokumen atau arsip yang berupa buku tentang latar belakang sejarah makam kuno Belanda (Kerhcof) sebagai sumber belajar sejarah lokal kepada masyarakat. Oleh karena itu, dalam tahapan yang dilakukan merupakan rangkaian yang memiliki keterkaitan. Adapun keterkaitan komponen antara tahap tersebut adalah sebagai berikut:

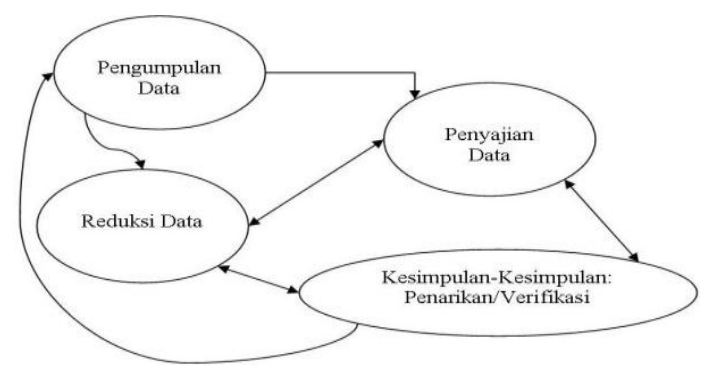

Gambar 1. Analisis data model interaktif, miles dan huberman

(dalam Sugiyono 2008: 247).

Hasil Dan Pembahasan

\section{A. Lokasi Makam Kuno Belanda (Kerkhof)}

Makam Kuno Belanda (Kerhcof) terletak di Kelurahan Pelem RT/RW 07/02 Kecamatan Ngawi Kabupaten Ngawi. Benteng Van Den Bosh (Benteng Pendem) berjarak $\pm 1 \mathrm{~km}$ dari Kota Ngawi ke arah timur laut menuju ke Kelurahan Pelem
Kecamatan Ngawi Kabupaten Ngawi. Tepatnya di Jl. Mongonsidi. Dari hasil wawancara dengan INF-06 dan INF-03 bahwa, luas area Makam $\pm 1,5$ ha, dibagi menjadi dua bagian yaitu bagian barat dan bagian timur. Bagian barat digunakan untuk pemakaman Belanda, sedangkan bagian timur untuk warga lokal Kelurahan Pelem.

\section{B. Sejarah Makam Kuno Belanda (Kerkhof)}

INF-03 menyatakan bahwa, makam Kerhcof di Pelem merupakan makam tentara sebelum Perang Dunia ke 2, pada pertengahan abad ke 18 (100 tahun sebelum Indonesia merdeka). Mereka tinggal di Benteng Pendem dalam kurun waktu yang lama, dan para tentara juga mengalami masa penuaan trus akhirnya mati. Lalu dibuatkan makam yang tidak jauh dari lokasi Benteng Pendem. Tidak hanya tentara Belanda saja, tetapi anak dan istri mereka juga (wawancara 25 Mei 2016).

Hal senada juga diungkapkan oleh INF-02 bahwa makam Kerhcof ini dulu digunakan untuk tentara Belanda yang tinggal atau bertugas di benteng Van Den Bosch. Tapi tidak hanya tentara saja, istri dan anak-anaknya ketika Belanda masih berkuasa di daerah benteng. Termasuk yang bertugas di PG Soedono yang dulu dikuasai Belanda sekitar tahun 1963

\section{Luas dan Benda-Benda di Makam Kuno Belanda (Kerkhof)}

Luas dari makam yaitu sekitar 1,5 hektar, dibagi menjadi dua bagian yaitu 
bagian barat dan timur. Untuk bagian barat dihuni oleh para tentara Belanda, sedangkan yang bagian timur dipakai oleh warga sekitar Kelurahan Pelem. Ada pembatas berupa tembok yang ada pintu ditengahnya yang memisahkan antara makam Belanda dengan makam lokal. (wawancara INF-06, 28 Mei 2016).

\section{Pengelolaan Makam Kuno Belanda (Kerkhof)}

Pengelolaan Makam Kuno Belanda (Kerkhof) saat ini di tangani oleh PEMDA Ngawi. Karena tanah tempat makam tersebut sudah diatasnamakan PEMDA. Jadi kalau ada yang ingin memakamkan di pemakaman tersebut harus meminta ijin ke PEMDA, tetapi ada batasan tahunnya, yaitu setiap lima tahun sekali harus mengurus ijin ulang. Istilahnya seperti pajak. (wawancara INF-03, 25 Mei 2016).

Sebenarnya makam ini masih satu lingkup dengan Benteng Pendem, tetapi sekarang wilayah benteng sudah disertifikatkan menjadi tiga bagian yaitu ARMED 12 mendapat bagian 16 hektar, MENHAM/LP mendapat bagian 5 hektar, sedangkan PEMDA mendapat bagian 4 hektar termasuk makam Kerhcof ini. Rencananya akan dilakukan pemugaran bersamaan dengan pemugaran Benteng Pendem yang didanai langsung oleh Negara Belanda yang sudah melakukan kesepakatan dengan pihak ARMED 12 dan PEMDA. Biaya yang akan dikeluarkan oleh Negara Belanda 19 trilyun. Pemugaran tersebut tidak menghilangkan bentuk aslinya, tetapi hanya melengkapi bagianbagian yang sudah hilang supaya kembali sama seperti wujud awal pembuatanya. Hal ini bertujuan supaya orang-orang Belanda yang berkunjung bisa mengetahui sejarah kakek/nenek mereka di Indonesia (wawancara INF-02 25 Mei 2016).

\section{E. Koleksi Makam Kuno Belanda (Kerkhof)}

Makam Belanda merupakan peninggalan tentara Belanda pada pertengahan abad ke 18, yang tinggal di Benteng Pendem. Makam ini memiliki \pm 300 koleksi makam dan benda peninggalan zaman Belanda. Koleksi makam dan bendabenda seperti yang diungkapkan oleh INF03 dan INF-06, diantaranya:

1. Bagian depan makam

Bagian depan makam terdapat gapura pintu masuk. Gapura tinggi besar dan kokoh ini mempunyai tinggi lubang pintu 5 meter, sementara total tingginya sekitar 7 meter.

2. Barisan makam paling depan

Barisan makam paling depan adalah deretan makam yangmemiliki cungkup terbuat dari besi. Makam ini mempunyai ukuran, bentuk, dan tinggi yang sama yaitu $1,5 \times 2,5$ meter.

3. Barisan makam kedua

Barisan makam kedua adalah deretan makam yang berbentuk seperti pion catur. Makam ini berjumlah 8 bangunan. 
4. Barisan makam ketiga

Barisan makam ketiga makam yang mempunyai ukuran paling besar diantara makam-makam yang lainya. Jumlah makam seperti ini adalah 6 bangunan.

5. Makam yang memiliki patung

Bentuk makam ini berjumlah 3 bangunan dan semuanya adalah makam wanita Belanda.

6. Makam berbentuk kerucut

Yang dimaksud dengan makam berbentuk kerucut adalah makam ini seperti tugu yang tingginya sekitar 4 meter dan barbentuk kerucut pada bagian atasnya. Jumlah makam seperti ini ada 7 bangunan.

\section{F. Nilai-nilai yang Bisa Diwariskan dari Makam Kuno Belanda (Kerkhof)}

Setiap benda atau bangunan yang berumur ratusan tahun pasti memiliki nilainilai budaya yang bisa kita pelajari. Nilainilai tersebut sangatlah bermanfaat bagi masyarakat khususnya para generasi muda, agar tumbuh rasa nasionalisme pada diri mereka.

Begitu pula Makam Kuno Belanda (Kerkhof) ini juga memiliki beberapa nilainilai yang bisa kita pelajari. Seperti yang diungkapkan oleh INF-03 nilai-nilai yang bisa diwariskan kepada masyarakat:

1. Nilai sejarah yakni masyarakat akan mengetahui sepak terjang bangsa Belanda saat menjajah Indonesia khususnya di Kabupaten Ngawi. Dengan begitu diharapkan mampu menumbuhkan rasa nasionalisme pada masyarakat dan generasi muda.

2. Nilai arsiktektur bangunan, yakni kita bisa melihat bahwa bangunan makam tersebut sama persis dengan bangunanbangunan yang ada di Eropa.

3. Nilai pendidikan, yakni kita harus selalu semangat pantang menyerah seperti yang dilakukan para pejuang kita melawan penjajah Belanda. Tetapi pada jaman sekarang tidak untuk melawah penjajah, melainkan semangat belajar demi meraih masa depan.

4. Nilai budaya, yakni makam tersebut masih ada hubunganya dengan Benteng Pendem yang menjadi salah satu icon penting bagi Kabupaten Ngawi yang akan menambah pendapatan daerah, serta menunjang ekonomi masyarakat sekitar benteng (wawancara 25 Mei 2016).

\section{G. Hubungan Makam Kuno Belanda (Kerkhof) dengan Benteng Van Den Bosh}

INF-06 mengungkapkan, bahwa terdapat hubungan antara makam kuno Belanda dengan Benteng Pendem, karena yang dimakamkan di sini itu para tentara dan keluarga yang tinggal di Benteng Pendem. (wawancara 28 Mei 2016). Sedangkan INF-05 juga mengatakan, Hubunganya makam dengan Benteng Pendem adalah makam tersebut merupakan salah satu bukti pendukung bahwa Belanda 
pernah tinggal di Ngawi dalam waktu yang sangat lama. (wawancara 01 Juni 2016).

\section{H. Pemanfaatan Makam Kuno Belanda (Kerkhof) Sebagai Sumber Belajar Sejarah}

Kegiatan belajar mengajar itu tidak hanya dilakukan di dalam kelas, namun bisa juga dilakukan di luar kelas misalnya berkunjung ke tempat-tempat bersejarah, ke museum, atau ke laboratorium. Khusus mata pelajaran IPS/sejarah itu perlu kegiatan belajar mengajar yang dilaksanakan di luar sekolah supaya terjadi kegiatan belajar mengajar yang menarik. Selain itu kalau kita belajar sejarah harus ada buktinya, karena kalau tidak ada buktinya bukan dikatakan sejarah. Yang dimaksud sebagai bukti itu bisa diartikan sebagai jejak-jejak peninggalannya, seperti bangunan, fosil, foto, surat, maupun rekaman video (wawancara INF-05 01 Juni 2016).

Hal senada juga disampaikan oleh INF-03 yaitu, Makam Belanda ini bisa dijadikan sebagai sumber belajar sejarah selain sumber dari buku, Makam Belanda (Kerhcof) merupakan peninggalanpeninggalan bangsa Belanda di Indonesia khususnya di Kabupaten Ngawi. Peserta didik kita diajak berkunjung ke benteng untuk mengamati atau observasi terhadap benda-benda peninggalan bangsa Belanda di Indonesia, khususnya di Kabupaten Ngawi ini. Selain bendanya juga cerita sejarahnya bisa diamati untuk meteri belajar merekaPemanfaatan yang ada kaitanaya dengan makam yaitu guna memberikan gambaran atau wujud asli tentang peninggalan-peninggalan Belanda yang pernah tinggal di Daerah Kelurahan Pelem ini dan supaya para pelajar lebih mempunyai rasa cinta tanah air. (wawancara 25 Mei 2016).

\section{Pembahasan}

\section{A. Sejarah Makam Kuno Belanda (Kerkhof)}

Makam Kuno Belanda atau yang sering disebut dengan sebutan Makam Kerhcof ini merupakan salah satu jejak peninggalan Kolonialisme Belanda di Kabupaten Ngawi. Makam Kuno Belanda ini terletak di Kelurahan Pelem RT/RW 07/02 Kecamatan Ngawi Kabupaten Ngawi. Makam Kuno Belanda (Kerhcof) dibangun pada tahun 1885 dibawah pimpinan Gubernur Jendral Van Den Bosch pada waktu menjajah daerah Ngawi.

Makam Kerhcof di Pelem merupakan makam tentara pada saat sebelum terjadi Perang Dunia ke 2. Pada pertengahan abad ke 18. Yaitu pada masa sekitar 100 tahun sebelum Indonesia merdeka. Karena mereka tinggal di Benteng Pendem dalam kurun waktu yang lama, dan para tentara juga mengalami masa penuaan terus dan akhirnya mati. Lalu dibuatkan makam yang tidak jauh dari lokasi Benteng Pendem. Tidak hanya tentara Belanda saja, tetapi anak dan istri mereka juga. Pada saat 
Tentara Belanda masih menguasai daerah Ngawi, makam ini dijaga ketat tentara Belanda. Tidak boleh ada warga lokal yang masuk makam, kecuali anak tentara Belanda. Tidak hanya tentara Belanda yang dimakamkan, tetapi juga tentara Jerman, yang dulu ceritanya ditawan Belanda, dan dijadikan prajurit Belanda. Termasuk juga yang bertugas di PG Soedono yang dulu dikuasai Belanda sekitar tahun 1963.

Luas dari makam yaitu sekitar 1,5 hektar, dibagi menjadi dua bagian yaitu bagian barat dan timur. Untuk bagian barat dihuni oleh para tentara Belanda, sedangkan yang bagian timur dipakai oleh warga sekitar Kelurahan Pelem. Ada pembatas berupa tembok yang ada pintu ditengahnya yang memisahkan antara makam Belanda dengan makam lokal.

Kalau bentuk cungkup berbeda dengan makam lokal pada umumnya. Beanda-benda yang berada di dalam makam diantaranya gapura besar pintu masuk, patung manusia bersayap (bayak orang menyebutnya patung Malaikat), cungkup seperti pion catur, cungkup seperti kerucut, pohon-pohon besar berumur ratusan tahun, pohon pisang.

Adapun besar kecilnya makam, tidak mempengaruhi tinggi rendahnya pangkat menjadi tentara Belanda. Akan tetapi itu hanya tergantung permintaan keluarga yang meninggal supaya memperindah penampilan saja. Pengelolaan makam tersebut sudah diambil alih oleh pihak
PEMDA. sebenarnya makam ini masih satu lingkup dengan Benteng Pendem, tetapi sekarang wilayah benteng sudah disertifikatkan menjadi tiga bagian yaitu ARMED 12 mendapat bagian 16 hektar, MENHAM/LP mendapat bagian 5 hektar, sedangkan PEMDA mendapat bagian 4 hektar termasuk makam Kerhcof ini.

Rencananya akan dilakukan pemugaran bersamaan dengan pemugaran Benteng Pendem yang didanai langsung oleh Negara Belanda yang sudah melakukan kesepakatan dengan pihak ARMED 12 dan PEMDA. Biaya yang akan dikeluarkan oleh Negara Belanda 19 trilyun. Pemugaran tersebut tidak menghilangkan bentuk aslinya, tetapi hanya melengkapi bagianbagian yang sudah hilang supaya kembali sama seperti wujud awal pembuatanya. Hal ini bertujuan supaya orang-orang Belanda yang berkunjung bisa mengetahui sejarah kakek/nenek mereka di Indonesia.

\section{B. Nilai-Nilai Yang Bisa Diwariskan dari Makam Kuno Belanda (Kerkhof)}

Makam Kuno Belanda termasuk dalam bangunan cagar budaya. Karena kalau benda cagar budaya itu bisa dipindah atau bisa bergerak, sedangkan bangunan cagar budaya itu tidak bisa dipindah atau tidak bisa bergerak kemanapun hanya ditempat tersebut saja. Hal ini relevan dengan Undang-Undang Republik Indonesia Nomor 11 tahun 2010 Tentang Cagar Budaya Pasal 1 ayat 3 bahwa, Bangunan Cagar Budaya adalah susunan binaan yang 
terbuat dari benda alam atau benda buatan manusia untuk memenuhi kebutuhan ruang berdinding atau tidak berdinding dan beratap. Selain itu Makam Kuno Belanda sampai saat ini sudah berumur mencapai 131 Thun. Sesuai kriteria ketetapan benda cagar budayabahwa benda atau bangunan bisa dikatakan sebagai benda cagar budaya haruslah memiliki sekurang-kurangnya umur 50 tahun.

Namun, setiap objek wisata tentunya memiliki nilai-nilai yang bisa kita $p$ [akai dalam kehidupan sehari-hari, karena nilai tersebut mengandung nilai yang luhur. Sebagai contoh benda dan bangunan cagar budaya. Mengingat setiap peristiwa yang terjadi pada masa lalu pasti meninggalkan jejak peristiwa yang bisa digunakan sebagai ilmu pengetahuan. Sesuai dengan pengertian sejarah menurut kamus besar bahasa Indonesia (1990: 794) ilmu, pengetahuan, cerita, pelajaran tentang kejadian dan peristiwa yang benar-benar terjadi pada masa lampau, atau juga disebut dengan riwayat.

Begitu pula Makam Kuno Belanda (Kerkhof) ini juga memiliki beberapa nilainilai yang bisa kita pelajari. Seperti yang diungkapkan oleh INF-03 nilai-nilai yang bisa diwariskan kepada masyarakat antara lain:

1. Nilai sejarah yakni

masyarakat untuk mengetahui sepak terjang atau keganasan bangsa Belanda saat menjajah Indonesia khususnya di
Kabupaten Ngawi. Dengan begitu mampu menumbuhkan rasa nasionalisme pada masyarakat dan generasi muda.

2. Nilai arsiktektur bangunan, yakni kita bisa melihat bahwa bangunan makam tersebut sama persis dengan bangunanbangunan yang ada di Eropa.

3. Nilai pendidikan, yakni kita harus selalu semangat pantang menyerah seperti yang dilakikan para pejuang kita melawan penjajah Belanda. Tetapi pada jaman sekarang tidak untuk melawah penjajah, melainkan semangat belajar demi masa depan.

4. Nilai budaya, yakni makam tersebut masih ada hubunganya dengan Benteng Pendem yang menjadi salah satu icon penting bagi Kabupaten Ngawi yang akan menambah pendapatan daerah, serta menunjang ekonomi masyarakat sekitar benteng.

\section{Makam Kuno Belanda (Kerkhof) sebagai Sumber Belajar Sejarah}

Menurut Association for Educational Communications an Technology (AECT) (dalam Komalasari, 2011: 108) mengatakan bahwa sumber pembelajaran adalah segala sesuatu atau daya yang dapat dimanfaatkan oleh guru, baik secara terpisah maupun dalam bentuk gabungan, untuk kepentingan belajar mengajar dengan tujuan meningkatkan efektifitas dan efesien pembelajaran.

Dalam meningkatkan efektifitas dan efesien pembelajaran seorang pengajar 
haruslah kreatif dan inovatif dalam mengadakan kegiatan belajar mengajar. Khusus pembelajaran sejarah seorang peserta didik bisa menambah wawasan pengetahuan dari sumber-sumber belajar selain buku. Seperti yang diungkapkan Saripuddin dan winataputra (dalam Djamarah dan Zain, 2010: 122) beliau mengelompokkan sumber-sumber belajar menjadi lima kategori, yaitu (1) manusia, (2) buku atau perpustakaan, (3) media massa, (4) alam lingkungan, dan (5) media pendidikan.

Keberadaan Makam Kuno Belanda (Kerkhof) secara khusus dapat dimanfaatkan oleh para pendidik dan peserta didik sebagai salah satu sumber belajar sejarah. Hal ini dapat dimasukkan ke dalam mata pelajaran IPS-sejarah dan diselaraskan dengan kurikulum serta silabus disemua jenjang pendidikan di SMP dan SMA. Cara penerapannya sebagai berikut:

1. Ditingkat SMP diterapkan pada mata pelajaran IPS kelas VIII semester I. Hal ini disesuaikan dengan Kurikulum 2013 pada Kompetensi Dasar 4.2 menyajikan hasil olahan telaah tentang peninggalan kebudayaan dan pikiran masyarakat Indonesia pada masa penjajahan dan tumbuhnya semangat kebangsaan dalam aspek geografis, ekonomi, budaya, pendidikan, dan politik yang ada di lingkungan sekitarnya. Dalam kegiatan belajar mengajar seorang pendidik dapat mengajak peserta didik berkunjung ke makam kuno Belanda (Kerhcof), tujuannya untuk melakukan pengamatan peninggalan-peninggalan bangsa Belanda di Ngawi. Harapannya setelah berkunjung ke makam tersebut peserta didik mengetahui secara nyata bahwa makam kuno Belanda merupakan salah satu peninggalan bangsa Belanda di Ngawi. Selain itu, untuk mengetahui tentang sejarah makam dan perjuangan rakyat Ngawi melawan bangsa Belanda.

Ditingkat SMA diterapkan pada mata pelajaran Sejarah kelas XI semester I. Hal ini disesuaikan dengan Kurikulum 2013 pada Kompetensi Dasar 4.1 mengolah informasi tentang peristiwa sejarah pada masa penjajahan bangsa Barat berdasarkan konsep perubahan dan keberlanjutan, dan menyajikannya dalam bentuk cerita sejarah. 4.2 mengolah informasi tentang proses masuk dan perkembangan penjajahan bangsa Barat di Indonesia dan menyajikannya dalam bentuk cerita sejarah.

Dalam penerapannya peserta didik diberi tugas untuk melakukan observasi ke Makam Kuno Belanda (Kerhcof) tentang peristiwa sejarah penjajahan bangsa Barat khususnya bangsa Belanda saat menjajah daerah Ngawi. Peserta didik diharapkan mampu mendapatkan informasi secara lengkap dengan 
melakukan wawancara kepada pengelola makam dan masyarakat sekitarnya.

\section{Penutup}

\section{A. Kesimpulan}

Sejarah Makam Kuno Belanda merupakan salah satu jejak peninggalan Kolonialisme Belanda di Kabupaten Ngawi. Makam Kuno Belanda dibangun pada tahun 1885 dibawah pimpinan Gubernur Jendral Van Den Bosch. Makam Kerkhof di Pelem merupakan makam tentara Balanda yang meninggal Sebelum pada saat sebelum Perang Dunia ke 2.

Pada akhir tahun 2011 Benteng Van Den Bosch baru dibuka sebagai tempat wisata edukasi di Kabupaten Ngawi. Pengelolaan sarana dan prasarana dikelola oleh Yon Armed Kostrad 12 Ngawi dan dibantu oleh Pemerintah Kabupaten Ngawi.

\section{B. Saran}

Berdasarkan hasil penelitian, maka saran bagi pengelolaan makam kuno Belanda untuk ditingkatkan seiring dengan adanya rencana revitalisasi bangunan benteng Van Den Bosch. Terutama tentang kebersihan di dalam Kompleks makam sebelah selatan yang rumput dan sema belukar cukup lebat. Karena akar dari semak-semak tersebut akan merusak bangunan makam. Untuk Pemerintah Kabupaten Ngawi agar meningkatkan perhatian dan kepedulian keberadaan Makam Kuno Belanda guna melengkapi wisata Benteng Van Den Bosch sebagai salah satu tempat wisata edukasi dan pelestarian bangunan peninggalan bersejarah demi kemajuan ilmu pengetahuan. Oleh karena makam tersebut belum tersentuh dengan baik dalam perawatannya. Sebab banyak arca-arca atau batu marmer dicuri dan dijual ke kolektor. Kepada guru mata pelajaran IPS-Sejarah harus lebih kreatif dalam melaksanakan kegiatan belajar mengajar agar siswa senang belajar sejarah.

Untuk para wisatawan baik lokal maupun asing untuk lebih sadar bahwa semua yang di tempat wisata harus dijaga dan dilestarikan baik dari segi lingkungan dan bangunan. Menjaga dan melestarikan bukan hanya kewajiban pengelola makam kuno Belanda saja, tetapi juga semua yang terlibat dalam lingkungan tersebut baik wisatawan maupun warga sekitar.

\section{Daftar Pustaka}

Aman. 2011. Model Evaluasi Pembelajaran Sejarah. Yogyakarta: Ombak.

Aunurrahman. 2009. Belajar dan Pembelajaran. Bandung: Alfabeta.

Djamarah, S. B., dan Zain, A., Strategi Belajar Mengajar. Jakarta: PT Rineka Cipta

Hamid, A. R., dan Madjid, M. S. 2011. Pengantar Ilmu Sejarah. Yogyakarta: Alfabeta

Komalasari, K., 2011. Pembelajaran Konstekstual Konsep dan Aplikasi. Bandung: PT Refika Aditama.

Moleong, L. J. 2012. Metodologi Penelitian Kualitatif. Bandung: PT Remaja

Nasional dan Masa Hindia Belanda. Jakarta: Balai Pustaka.

Nazir, M. 2009. Metode Penelitian. Bandung: Ghalia Indonesia. Ombak. 
Poesponegoro, M. D. 2008. Sejarah Nasional Indonesia IV Kemunculan Penjajahan di Indonesia. Jakarta: Balai Pustaka

Silalahi, G. A. 2003. Metodologi Penelitian dan Studi Kasus. Sidoarjo: Citra Media.

Slameto. 1991. Proses Belajar mengajar Dalam Sistem Kredit Semester. Jakarta: Bumi Aksara.

Sugiyono. 2008. Metode Penelitian Kuantitatif, Kualitatif dan $R \quad \& D$. Bandung: Alfabeta.

Sutopo, H. B. 2002. Metodologi Penelitian Kualitatif. Surakarta: Sebelas Maret University Press.

Tim Penyusun Kamus Pusat Pembinaan dan Pengembangan Bahasa. 1990. Kamus Besar Bahasa Indonesia. Jakarta: Balai Pustaka

Widja, I. 1991. Sejarah Lokal Suatu Perspektif Dalam Pengajaran Sejarah. Bandung. Angkasa.

Yulia, A., 2015. Makam Keramat Ronggo Galih Di Desa Durenan Kecamatan Plaosan Kabupaten Magetan (Bentuk Arsitektur Dan Potensinya Sebagai Sumber Belajar Sejarah Lokal. Skripsi. Madiun: Program Studi Pendidikan Sejarah IKIP PGRI MADIUN. Unpublished

Jurnal:

Sitepu, BP. 2008. Pengembangan Sumber Belajar. Jurnal Pendidikan Penabur, 11 (11):85.

Tesis:

Supardi. 2005. Pendidikan Sejarah Lokal Dalam konteks Multikulturalisme. Tesis tidak diterbitkan. Yogyakarta: Universitas Negri Yogyakarta. Unpublished

Internet:

Ahmad, T. A. 2013. Pembelajaran Sejarah Berwawasan Lingkungan. Indonesian Journal of Conservation (Online), Jilid 2, No. 1, (http://www.azinarahmad@gmail.c om, Diunduh 11 Mei 2016).
Kurniawan, H. 11 Agustus 2013. Benteng Pendem. Benteng Pendem Van DenBosch (Ngawi-Jawa Timur). (Online),

Https://www.facebook.com/notes/harikurniawan/benteng-pendem-vanden-bosch-ngawi-jawatimur/577887378916622, Diunduh 6 Maret 2015). 